\title{
Brachiaria brizantha Grass as a Feedstock for Ethanol Production
}

\section{Rosilene Souza Rodrigues ${ }^{1}$}

https://orcid.org/0000-0002-3693-8004

Maíra Nicolau de Almeida ${ }^{1,2^{*}}$

https://orcid.org/0000-0003-1865-9957

\section{Gabriela Piccolo Maitan-Alfenas ${ }^{1}$}

https://orcid.org/0000-0003-2340-0077

Rafaela Zandonade Ventorim ${ }^{1}$

https://orcid.org/0000-0002-3812-627x

\author{
Sirlene Rodrigues Sartori ${ }^{3}$ \\ https://orcid.org/0000-0003-0779-5793
}

Evan Michael Visser ${ }^{1}$

https://orcid.org/0000-0003-3255-9418

Valéria Monteze Guimarães ${ }^{1}$

https://orcid.org/0000-0002-0735-6144

Sebastião Tavares de Rezende ${ }^{1}$

https://orcid.org/0000-0002-2968-6304

${ }^{1}$ Federal University of Viçosa, Department of Biochemistry and Molecular Biology, Viçosa, Minas Gerais, Brazil; ${ }^{2}$ Federal University of São João del Rei, Department of Natural Science, São João del Rei, Minas Gerais, Brazil; ${ }^{3}$ Federal University of Viçosa, Department of Animal Biology, Viçosa, Minas Gerais, Brazil.

Editor-in-Chief: Paulo Vitor Farago

Associate Editor: Ana Cláudia Barana

Received: 2020.06.10; Accepted: 2021.02.19.

*Correspondence: malmeida@ufsj.edu.br; Tel.: +55-32-33795163 (M.N.A.)

\section{HIGHLIGHTS}

- Brachiaria brizantha proved to be a promising biomass for ethanol production.

- Fermentation was not impaired by the inhibitors furfural and hydroxymethylfurfural.

Abstract: Different lignocellulosic biomasses are found worldwide and each country has its own important industrial crop that can be converted into high-value products, such as ethanol. Therefore, evaluation of new biomasses to be used in biorefineries is important to decrease the dependence on non-renewable resources and to guarantee sustainable development. This work evaluated Brachiaria brizantha, a grass commonly used as animal forage, and the standard biomass for 2G-ethanol, sugarcane bagasse. The chemical compositions of both biomasses were determined and different times and temperature of acid pretreatment were tested. Morphological analysis via scanning electron microscopy showed more deconstructed fibers after harsher biomass pretreatments. Simultaneous saccharification and fermentation of pretreated Brachiaria brizantha presented higher efficiency than when using sugarcane bagasse as the carbon source. A biomass conversion of $46 \%$ was achieved when Brachiaria brizantha grass was pretreated with $2 \%$ sulfuric acid for 60 minutes. Moreover, fermentation was not impaired by the inhibitors furfural and hydroxymethylfurfural. It was concluded that Brachiaria brizantha is a promising biomass for ethanol production.

Keywords: Ethanol; acid pretreatment; simultaneous saccharification and fermentation; sugarcane bagasse; Brachiaria brizantha. 


\section{INTRODUCTION}

The world energy supply is based predominantly on fossil fuels. However, burning these fuels contributes to increase greenhouse gas emissions which harms environment. Fossil fuels are also non-renewable and their supply will dwindle over time. Increasing the use of renewable energy sources is an important contribution to increase sustainable development. Biofuels are essential in this context, since they can provide energy with less impact on the environment [1]. Second generation ethanol (2G-ethanol) is an alternative renewable energy. It is produced from lignocellulosic biomasses, obtained from agroindustrial residues such as sugarcane bagasse [2,3]. Lignocellulosic materials consist of a hard and fibrous matrix, where flexible fibers, cellulose and hemicellulose are embedded in a lignin matrix, forming an extremely recalcitrant structure. Cellulose hydrolysis releases glucose while hemicellulose hydrolysis releases diverse sugars depending on the source. Xylan, the main hemicellulose for ethanol production, is composed by a chain of xylose branched with xylose, glucose, arabinose, glucuronic acid and others. Lignin can be found in plant materials in nature or as byproducts of their processing, and it is composed of a mixture phenylpropanoids [4]. Wood and non-wood materials are potential sources of lignocellulose. Non-wood material refers to agricultural residues and other fibers like switchgrass and cotton fiber. From an environmental standpoint, the use of non-wood material is more sustainable and environmentally friendly. Some promising non-wood materials are cereal straws and sugarcane bagasse. Cereal straws obtained after processing of barley, corn, oat, rice, sorghum and wheat are promising sources that account for 2367.3 million of ton/year [5]. Sugarcane bagasse and straw are byproducts from sugarcane processing for sugar and ethanol production. Sugarcane bagasse is especially important in Brazil, the second greatest ethanol producer in the world, behind the USA. The 2018/2019 Brazilian sugarcane harvest was 620.44 million tons [6], from which $8,732.59$ million of gallons of ethanol were produced [7]. The percentage of sugarcane bagasse availability is estimated to be $25 \%$ per ton of ground sugarcane, whereas sugarcane straw accounts for $14 \%$ per ton of sugarcane harvest. These residues are burned for bioelectricity or used for $2 \mathrm{G}$-ethanol production [8].

Herbaceous crops, such as grasses, are also studied with regards to their potential for 2G-ethanol production. These plants are relatively easy to grow, harvest and process. Grass can grow globally in a wide range of geographies, climates and soil types [5]. Brachiaria is a genus of the Poaceae family which includes at least 100 species found in tropical and subtropical regions of America, Asia, Oceania and Africa [9]. The African grass Brachiaria brizantha is highly competitive and accumulates large amounts of biomass. This is the most common and aggressive exotic grass found in the Brazilian Cerrado and it is commonly used as forage for animal feed [10]. It is estimated that grazing areas in Brazil accounted for 149.670.217 ha in 2017, and about $80 \%$ is cultivated with Brachiaria. In Africa, a natural region of Brachiaria brizantha, this grass produces approximately $40 \mathrm{t} / \mathrm{ha} / \mathrm{year}[11,12]$. Brachiaria brizantha grows well in the tropics and subtropics and shows a high photosynthetic efficiency (C4 plant), i.e., it has a high capacity for transforming solar energy into biomass. The dry matter yield of Brachiaria brizantha is about 20 ton/ha [9]. In addition, grasses also have the advantage of presenting pre-existing cultivars specifically created to improve animal digestibility (higher fiber content), which also favors their use for energy purposes. Some grass species grow to a height of $15-20 \mathrm{~cm}$, but others can grow to more than $1 \mathrm{~m}$ tall [9]. In biotechnological approaches, forages have been studied for production of ethanol [13], biomethane production [14], cellulase and hemicellulase induction [15] and as a cellulose source for material synthesis [16].

Ethanol production from lignocellulosic biomasses includes three major steps: pretreatment, hydrolysis and fermentation. Mechanical and chemical pretreatments are performed to open the lignocellulose structure and allow enzymes access to polysaccharides for hydrolysis. According to the applied pretreatment, removal of hemicellulose or lignin in different proportions may occur, with reduction in cellulose crystallinity and increased porosity, thereby increasing the residual solid digestibility. Furthermore, an effective treatment can substantially reduce the enzyme cocktail loading required for cellulose hydrolysis, which significantly reduced the overall costs [17]. Pretreatment is a challenge for 2G-ethanol feasibility and is an important bottleneck for the industrial process [18]. Industrially, the acid and organosolv processes are reported to be used [19]. Acid pretreatment is widely used and efficiently removes hemicellulose, where the most common acid for pretreatment is sulfuric acid [20-22]. Other acids can also be used, including hydrochloric acid [20], nitric acid [23] and phosphoric acid [24]. However, some released byproducts such as furfural and hydroxymethylfurfural, derived from sugars acid hydrolysis, can decrease fermentation performance. Other important fermentation inhibitors are formic acid, acetic acid, levulinic acid, and phenolic compounds [25]. Additional pretreatments are under study such as mild alkaline [26], oxidative [27], aqueous ammonia and steam explosion [28], as well as some combined techniques [24,29]. 
Pretreatment conditions such as chemical concentration, temperature and pressure can dramatically increase fiber disorganization, but also increase carbohydrate destruction and release of fermentation inhibitors. Therefore, the optimization of pretreatment parameters for the different types of lignocellulosic biomasses plays a crucial role in increasing the conversion efficiency of the bioethanol production process. Delignification and hemicellulose removal efficiency, sugar losses, processing time, economic issues and environmental impact are important parameters for selecting the right pretreatment [1]. Thus, this work aimed to analyze several conditions of acid pretreatment severity on the forage biomass Brachiaria brizantha and on sugarcane bagasse, which is a common biomass in Brazil, in order to compare these two biomasses in different conditions. The analysis of pretreatment severity was performed by determining the chemical composition of the pretreated biomass and quantifying the inhibitor concentrations (furfural and hydroxymethylfurfural) in the hemicellulosic hydrolysate. Finally, Simultaneous Saccharification and Fermentation (SSF) of the pretreated samples was performed to compare the final ethanol yield after each treatment.

\section{MATERIAL AND METHODS}

\section{Biomasses}

The sugarcane bagasse (Saccharum spp) and grass (Brachiaria brizantha cv. xaraés) biomasses were obtained at the Experimental Units of the Federal University of Viçosa in Viçosa, Minas Gerais, Brazil. Forage cutting was performed in March 2008, leaves were $20 \mathrm{~cm}$ and in the frequency of $95 \%$ light interception. The biomasses were dried outdoor, ground and stored at room temperature.

\section{Pretreatments}

Dilute acid pretreatments were performed according to the methodology described by Falkoski and coauthors [21], with some adjustments. Biomasses samples were treated with solutions of sulfuric acid $\left(\mathrm{H}_{2} \mathrm{SO}_{4}\right)$ at concentrations of $0.5,1$ and $2 \%(\mathrm{v} / \mathrm{v})$. The samples $(10 \mathrm{~g})$ were dried and added to $250 \mathrm{~mL}$ Erlenmeyer flasks containing $100 \mathrm{~mL}$ of the sulfuric acid solutions and then autoclaved at $121^{\circ} \mathrm{C}$ for 30,60 and $90 \mathrm{~min}$. The proportion of acid/biomass in $\mathrm{g} / \mathrm{g}$ was $0.0475,0.095$ and 0.190 considering the reagent purity of $95 \%$. The solids concentration in the medium was always $10 \%(\mathrm{~m} / \mathrm{v})$ and each treatment was performed in duplicate. For determination of reducing sugar and inhibitor concentrations, the samples were filtered and washed with warm deionized water. The liquid fraction, resulting from washing and filtration of the pre-treated biomass, was used in the analysis. The solid fraction was collected and stored for chemical composition analysis. Samples were stored at $4{ }^{\circ} \mathrm{C}$ prior to analysis.

\section{Microorganism and inoculum preparation}

For simultaneous saccharification and fermentation (SSF) experiments, the yeast Saccharomyces cerevisiae YRH400 was used. It was kindly donated by the USDA (United States Department of Agriculture) and it is an engineered strain to express specific genes to assimilate xylose. The yeast was maintained on solid medium containing $1 \%(\mathrm{w} / \mathrm{v})$ peptone, $1 \%(\mathrm{w} / \mathrm{v})$ glucose, $1 \%(\mathrm{w} / \mathrm{v})$ yeast extract and $1 \%(\mathrm{w} / \mathrm{v})$ agar, incubated at $30^{\circ} \mathrm{C}$ for $24 \mathrm{~h}$ and stored under refrigeration $\left(4^{\circ} \mathrm{C}\right)$. The inoculum was grown in YPD medium consisting of $1 \%(\mathrm{w} / \mathrm{v})$ yeast extract, $2 \%(\mathrm{w} / \mathrm{v})$ glucose and $2 \%(\mathrm{w} / \mathrm{v})$ peptone. The culture was agitated in a rotary incubator $(150 \mathrm{rpm})$ at $30 \stackrel{\circ}{\mathrm{C}}$ for $20 \mathrm{~h}$.

\section{Simultaneous Saccharification and Fermentation (SSF)}

For SSF, the biomasses were pretreated as described previously and the liquid fractions obtained were separated from the solid biomass but without the washing step. Prior to the SSF process, the pretreated biomasses were pre-hydrolyzed using the commercial cellulase solution Multifect $\mathrm{CL} \circledast$ (Genencor). Composition of the medium used in the SSF process included yeast extract $2.5 \mathrm{~g} / \mathrm{L}$, ammonium sulfate $1 \mathrm{~g} / \mathrm{L}$, potassium phosphate $1 \mathrm{~g} / \mathrm{L}$ and magnesium sulfate $0.5 \mathrm{~g} / \mathrm{L}$. The solids loading was $3 \%$ and enzyme concentration was $20 \mathrm{FPU} / \mathrm{g}$ of dry mass. This high enzyme load was employed to exploit the maximum available sugars in order to assess the pretreatment stage. Pre-hydrolysis was carried out for $8 \mathrm{~h}$ at $50^{\circ} \mathrm{C}$ under agitation at $150 \mathrm{rpm}$ in phosphate buffer $0.1 \mathrm{~mol} / \mathrm{L}, \mathrm{pH} 6.0$. The temperature was then adjusted to 30 ${ }^{\circ} \mathrm{C}$ and the yeast inoculum was added to the reaction medium in a final optical density (OD 600nm) of 1.0. SSF was carried out for $28 \mathrm{~h}$. Aliquots of $1 \mathrm{~mL}$ were withdrawn at different time intervals, centrifuged at $16.100 \mathrm{~g}$ for $10 \mathrm{~min}$ and stored at $-20^{\circ} \mathrm{C}$ for subsequent analysis. 
Analytical Methods

\section{Analysis of the carbohydrate and lignin contents of biomasses}

Carbohydrate concentrations of the treated and untreated samples was determined by High Performance Liquid Chromatography (HPLC) according to Wallis, eta al [30]. For the untreated samples, the soluble lignin was quantified by the method proposed by [25], and the insoluble lignin analysis was performed according to Gomide \& Demuner [31]. To quantify carbohydrates and lignin, low molecular weight organic substances, denominated extractives, were previously removed from the samples because these compounds may interfere with the analysis results. Extractives were extracted in a soxhlet apparatus using $125 \mathrm{~mL}$ of acetone. After 5 hours, samples were removed from the apparatus and maintained at constant temperature and humidity. For determination of the moisture content, approximately $300 \mathrm{mg}$ of the samples were dried at $105^{\circ} \mathrm{C}$ until reaching a constant weight.

\section{Quantification of furfural and hydroxymethylfurfural}

Furfural of the hemicellulosic hydrolysate was quantified according to Nascimento and coauthors [32]. The assay contained $0.9 \mathrm{~mL}$ of the samples, $0.9 \mathrm{~mL}$ of $95 \%(\mathrm{v} / \mathrm{v})$ ethanol, $0.02 \mathrm{~mL}$ of aniline and $0.4 \mathrm{~mL}$ of glacial acetic acid. The reaction was performed in the dark and with stirring for $15 \mathrm{~min}$. Samples were analyzed in a spectrophotometer at $510 \mathrm{~nm}$. Quantification was performed using a standard curve, constructed from successive dilutions of a standard solution of $0.02 \%(w / v)$ furfural. All analyses were performed in triplicate.

For quantification of hydroxymethylfurfural assays were performed with $0.4 \mathrm{~mL}$ of the samples, $1 \mathrm{~mL}$ of $10 \%(\mathrm{~m} / \mathrm{v})$ paratoluidine (diluted in $10 \mathrm{~mL}$ of acetic acid and $90 \mathrm{~mL}$ of isopropanol) and $0.2 \mathrm{~mL}$ of $5 \%(\mathrm{v} / \mathrm{v})$ barbituric acid. The assay was analyzed in a spectrophotometer at $550 \mathrm{~nm}$. The highest absorbance was achieved between 3 and 5 minutes. Quantification was performed using a standard curve, constructed with $5-40 \mathrm{mg} / \mathrm{L}$ from successive dilutions of the standard solution of $1 \mathrm{~g} / \mathrm{L}$ hydroxymethylfurfural. All analyses were performed in triplicate [33].

\section{Simultaneous saccharification and fermentation products analysis}

Determination of glucose, xylose, cellobiose and ethanol concentrations in the samples resulting from SSF was performed by High Performance Liquid Chromatography (HPLC) with an HPX-87P column (BioRad) using water as the mobile phase at a flow rate of $1 \mathrm{~mL} / \mathrm{min}$ and a separation temperature of $80^{\circ} \mathrm{C}$.

The ethanol yield $\left(\mathrm{Y}_{\mathrm{Et}}\right)$ was calculated as follow:

$$
Y_{E t}=\frac{E_{f}-E_{i}}{0.567 \times G} \times 100
$$

Where $Y_{E t}$ is the ethanol yield (\%), $E_{f}$ is the final ethanol mass $(g), E_{i}$ is the initial ethanol mass $(g), G$ is the glucan mass of the pretreated biomass $(\mathrm{g})$ and 0.567 is the stoichiometric ethanol yield from cellulose.

\section{Scanning electron microscopy}

For morphological visualization of the degree of destruction of pretreated biomasses, treated samples were collected from the mildest and severest pretreatments along with untreated samples (control). These were placed on stubs, metallized with gold and examined under an electron microscope (LEO VP1430).

\section{RESULTS AND DISCUSSION}

\section{Biomasses Composition}

Characterization of the biomass compositions is one of the most important steps to investigate their potential for biotechnological applications since the composition defines the properties and quality of different agricultural residues [34]. The chemical composition of different biomasses depends on several factors including plant species or part of the plants, growth processes, harvesting time [35], plant age [36], as well as fertilizer and pesticide doses used [37]. Table 1 shows the chemical composition of Brachiaria brizantha grass and sugarcane bagasse. 
Table 1. Chemical composition of the lignocellulosic biomasses Brachiaria brizantha and sugarcane bagasse (Saccharum spp).

\begin{tabular}{lcc}
\hline Composition $(\%)$ & Sugarcane bagasse & Brachiaria brizantha \\
\hline Glucans & 43.20 & 42.15 \\
Xylans & 21.50 & 12.70 \\
Galactans & 0.60 & 0.50 \\
Mannans & 0.35 & 0.55 \\
Arabinans & 2.20 & 0.80 \\
Lignin & 20.20 & 18.80 \\
\hline
\end{tabular}

The contents of lignin and hemicellulose in $B$. brizantha grass and sugarcane bagasse were 18.8 and 14.5, and 20.2 and $24.6 \%$, respectively. These two polymers interact with cellulose to form a recalcitrant structure that prevents cellulases from accessing cellulose, which later reduces saccharification yields and ethanol production. Due to this negative correlation, low lignin and hemicellulose contents are interesting for second generation ethanol production from cellulose $[17,38]$. Therefore, to enhance enzymatic degradability of cellulose, pretreatments that solubilize hemicelluloses and reduce lignin contents are preferred [39].

The cellulose content was very similar between $B$. brizantha grass and sugarcane bagasse (42 and 43 $\%$, respectively). These values are high when compared to literature, where normally the cellulose content of forage grasses is around 32 to $35.6 \%$ while in vetiver grasses this content varies between 31.8 and 38.5 $\%$ [40]. Gamba grass shows a cellulose content of about 26-32\%, hemicellulose between $21-33 \%$ and lignin of $2-9 \%$ [15]. With regards to sugarcane bagasse, studies have reported cellulose contents of $34 \%$ [19], 35 $\%$ [36] and $39 \%$ [41], hemicellulose concentrations of $26 \%$ [41], $23 \%$ [26] and $24 \%$ [42], and a lignin content of $22 \%$ [42-44] but some samples can show up to $30 \%$ [26].

\section{Biomass Pretreatments}

For bioethanol production, the most favorable results after a dilute acid pretreatment are preservation of cellulose, high reducing sugar quantities and a low concentration of inhibitors [45]. Tables 2 and 3 show, respectively, the carbohydrate content of the pretreated biomasses and inhibitor concentrations in the eluted fractions after different dilute acid pretreatment conditions.

Table 2. Carbohydrates concentrations in the biomass samples pretreated with sulfuric acid at concentrations of $0.5,1$ and $2 \%$.

\begin{tabular}{|c|c|c|c|c|c|c|c|}
\hline \multirow{3}{*}{ Biomass } & \multirow{3}{*}{$\begin{array}{c}\mathrm{H}_{2} \mathrm{SO}_{4} \\
\text { concentra } \\
\text { tion (\%) }\end{array}$} & \multicolumn{3}{|c|}{ Glucans (\%) } & \multicolumn{3}{|c|}{ Xylans (\%) } \\
\hline & & \multicolumn{6}{|c|}{ Reaction time (min) } \\
\hline & & 30 & 60 & 90 & 30 & 60 & 90 \\
\hline \multirow{3}{*}{$\begin{array}{c}\text { Brachiaria } \\
\text { brizantha }\end{array}$} & 0.5 & $42.85 \pm 2.25^{\mathrm{aA}}$ & $44.10 \pm 0.00^{\mathrm{aA}}$ & $46.00 \pm 0.75^{\mathrm{aA}}$ & $12.10 \pm 0.10^{\mathrm{aA}}$ & $9.78 \pm 0.00^{\mathrm{aA}}$ & $8.13 \pm 2.36^{\mathrm{aA}}$ \\
\hline & 1 & $45.12 \pm 0.28^{a A}$ & $50.50 \pm 0.70^{\mathrm{aB}}$ & $51.55 \pm 1.95^{\mathrm{aB}}$ & $9.38 \pm 0.26^{\mathrm{aB}}$ & $7.85 \pm 1.05^{\mathrm{aA}}$ & $6.17 \pm 0.17^{\mathrm{aA}}$ \\
\hline & 2 & $50.70 \pm 0.89 \mathrm{aB}$ & $53.32 \pm 0.98 \mathrm{aB}$ & $54.63 \pm 0.63 \mathrm{aB}$ & $4.57 \pm 0.00^{\mathrm{aC}}$ & $4.07 \pm 0.13 \mathrm{aB}$ & $3.39 \pm 0.01 \mathrm{aB}$ \\
\hline \multirow{3}{*}{$\begin{array}{c}\text { Sugarcane } \\
\text { bagasse }\end{array}$} & 0.5 & $61.15 \pm 0.75^{\mathrm{aA}}$ & $64.00 \pm 0.60 \mathrm{bA}$ & $67.60 \pm 0.00 \mathrm{cA}$ & $9.95 \pm 0.05^{\mathrm{aA}}$ & $7.00 \pm 0.00^{\mathrm{bA}}$ & $6.00 \pm 0.00^{\mathrm{cA}}$ \\
\hline & 1 & $62.40 \pm 0.40 \mathrm{aA}$ & $65.55 \pm 0.55^{\mathrm{bB}}$ & $68.05 \pm 0.05^{\mathrm{cA}}$ & $8.25 \pm 0.05^{a B}$ & $7.15 \pm 0.15^{\mathrm{bA}}$ & $4.60 \pm 0.00^{\mathrm{cB}}$ \\
\hline & 2 & $61.15 \pm 0.15^{\mathrm{aA}}$ & $65.35 \pm 0.35 \mathrm{bB}$ & $68.25 \pm 1.15^{\mathrm{cA}}$ & $5.35 \pm 0.15^{\mathrm{aC}}$ & $3.90 \pm 0.10^{b B}$ & $4.10 \pm 0.30 \mathrm{bB}$ \\
\hline
\end{tabular}

*Identical capital letters in the column and lowercase letters in the row do not significantly differ $(P>0.05)$. 
Table 3. Furfural and hydroxymethylfurfural (HMF) concentrations in the hydrolysates.

\begin{tabular}{|c|c|c|c|c|c|c|c|}
\hline \multirow{3}{*}{ Biomass } & \multirow{3}{*}{$\begin{array}{c}\mathrm{H}_{2} \mathrm{SO}_{4} \\
\text { concentration } \\
(\%)\end{array}$} & \multicolumn{3}{|c|}{ Furfural (mg.g ${ }^{-1}$ dry biomass) } & \multicolumn{3}{|c|}{ HMF (mg.g ${ }^{-1}$ dry biomass) } \\
\hline & & \multicolumn{6}{|c|}{ Reaction time (min) } \\
\hline & & 30 & 60 & 90 & 30 & 60 & 90 \\
\hline \multirow{3}{*}{$\begin{array}{c}\text { Brachiaria } \\
\text { brizantha }\end{array}$} & 0.5 & $0.35 \pm 0.02^{\mathrm{aA}}$ & $0.41 \pm 0.01^{\mathrm{bA}}$ & $0.54 \pm 0.01^{\mathrm{cA}}$ & $0.24 \pm 0.01^{\mathrm{aA}}$ & $0.99 \pm 0.04^{\mathrm{bA}}$ & $1.16 \pm 0.10^{\mathrm{bA}}$ \\
\hline & 1 & $1.33 \pm 0.02^{\mathrm{aB}}$ & $2.55 \pm 0.053^{\mathrm{bB}}$ & $4.10 \pm 0.07^{\mathrm{cB}}$ & $0.71 \pm 0.06^{\mathrm{aB}}$ & $0.99 \pm 0.19^{\mathrm{aA}}$ & $1.77 \pm 0.01^{\mathrm{bB}}$ \\
\hline & 2 & $2.08 \pm 0.19 \mathrm{aC}$ & $2.55 \pm 0.16^{\mathrm{aB}}$ & $4.16 \pm 0.18^{\mathrm{bB}}$ & $1.58 \pm 0.01^{\mathrm{aC}}$ & $2.18 \pm 0.12^{\mathrm{bB}}$ & $4.54 \pm 0.05^{\mathrm{cC}}$ \\
\hline \multirow{3}{*}{$\begin{array}{l}\text { Sugarcane } \\
\text { bagasse }\end{array}$} & 0.5 & $0.51 \pm 0.01^{\mathrm{aA}}$ & $0.85 \pm 0.06^{\mathrm{bA}}$ & $1.31 \pm 0.01^{\mathrm{cA}}$ & $6.06 \pm 1.05^{\mathrm{aA}}$ & $17.44 \pm 0.25^{\mathrm{bA}}$ & $23.33 \pm 0.18^{\mathrm{cA}}$ \\
\hline & 1 & $1.19 \pm 0.04^{\mathrm{aB}}$ & $2.08 \pm 0.17^{\mathrm{bB}}$ & $3.68 \pm 0.11^{\mathrm{cB}}$ & $8.11 \pm 0.25^{\mathrm{aA}}$ & $17.44 \pm 2.45^{\mathrm{bA}}$ & $23.72 \pm 0.49^{\mathrm{cA}}$ \\
\hline & 2 & $3.25 \pm 0.10^{\mathrm{aC}}$ & $4.41 \pm 0.56^{\mathrm{aC}}$ & $9.19 \pm 0.39 \mathrm{bc}$ & $20.27 \pm 0.92^{\mathrm{aB}}$ & $35.45 \pm 1.54^{\mathrm{bB}}$ & $42.68 \pm 1.29^{\mathrm{cB}}$ \\
\hline
\end{tabular}

*Identical capital letters in the column and lowercase letters in the row do not significantly differ $(P>0.05)$.

The most severe acid pretreatment tested, using $2 \%$ sulfuric acid for 90 minutes, was able to remove a greater xylan fraction and the higher hemicellulosic fraction removal was observed for sugarcane bagasse, $81 \%$, while $73.3 \%$ of xylan was removed from B. brizantha grass. Contrary to the results obtained for sugarcane bagasse, the milder acid pretreatment condition, using $0.5 \%$ sulfuric acid for 30 minutes, did not effectively removal xylan from Brachiaria grass. However, at this condition the removal of xylan from bagasse exceeded $50 \%$ while less than $5 \%$ of the initial content was removed for $B$. brizantha grass. Acid hydrolysis consists of dissolving hemicellulose through lignin disruption [46]. B. brizantha grass showed a lignin/hemicellulose ratio of 1.3 , while for sugarcane bagasse this ratio was 0.8 . Thus, the higher lignin proportion shown by the grass, in relation to the hemicellulosic fraction, requires a more severe pretreatment condition to enable more effective xylan removal. Sun and Cheng (2005) tested different acid pretreatment conditions of wheat straw and Cynodon dactylon grass and they observed that 50-66\% of xylan was removed from these biomasses using sulfuric acid in concentrations higher than $1.2 \%$ with retention times superior to 60 minutes [47]. Maitan-Alfenas and coauthors observed a $62 \%$ removal of hemicellulose after a dilute acid pretreatment using $1 \%$ sulfuric acid for 60 minutes [26].

Redding and coauthors evaluated different acid concentrations (0.3, 0.6, 0.9 and $1.2 \%)$, temperatures $\left(120,140,160\right.$ and $\left.180^{\circ} \mathrm{C}\right)$ and times $(5,15,30$ and 60 minutes) to establish the best conditions of dilute acid pretreatment for Bermuda grass. The authors reported that increasing the pretreatment severity resulted in a larger solubilized hemicellulose fraction, but also caused degradation of carbohydrates and produced fermentation inhibitors such as furfural and hydroximethylfurfural (HMF) [48].

Glucan concentrations varied from 42.85 to $54.63 \%$ for pretreated $B$. brizantha and from 61.15 to 68.25 $\%$ for pretreated sugarcane bagasse (Table 2). The increased glucan concentration was expected due to the removal of hemicellulose which was more pronounced for sugarcane bagasse under all tested pretreatment conditions and was most evident under the most severe conditions. For $B$. brizantha grass, the highest glucan concentrations were also observed under the most severe pretreatment conditions, in which there was a significant removal of the hemicellulosic fraction.

One of the most well-known drawbacks of acid pretreatments is the formation of compounds like furfural that come from pentose hydrolysis and HMF from hexose hydrolysis. Furfural and HMF inhibit yeast growth, thus decreasing the biofuel production yields [49]. In general, production of inhibitors from sugarcane bagasse and $B$. brizantha grass was more pronounced under the most severe pretreatment conditions (Table 3 ), indicating a possible loss of the cellulosic fraction which reduces the efficiency of the pretreatment methods. For furfural release from $B$. brizantha, the acid concentration was more important when the 30 minutes pretreatment was performed. No significant difference was observed between 1 or $2 \%$ acid when pretreatment was conducted for 60 minutes. The same was observed for the 90 minute pretreatment, where furfural concentrations resulting from 1 or $2 \%$ acid were statistically equal. For HMF release from $B$. brizantha, it is possible to observe combined effects between time and acid concentration. A higher HMF concentration ( $4.54 \mathrm{mg} / \mathrm{g}$, equivalent to $0.454 \mathrm{~g} / \mathrm{L}$ ) was observed for the most severe pretreatment ( $2 \%$ acid, 90 minutes). A similar result was observed for furfural release from sugarcane bagasse, where the harshest conditions resulted in higher furfural concentrations $(4.16 \mathrm{mg} / \mathrm{g}$, equivalent to $0.416 \mathrm{~g} / \mathrm{L})$. Regarding HMF release from sugarcane bagasse, the pretreatment time was a more significant factor when 0.5 or $1 \%$ acid was used, and similarly the HMF concentration was not different between the two acid concentrations tested. However, when using $2 \%$ acid the HMF concentrations were higher than for 0.5 and $1 \%$, and the time was also significant. The harshest condition resulted in $42.68 \mathrm{mg} / \mathrm{g}(4.268 \mathrm{~g} / \mathrm{L})$ of HMF produced from sugarcane 
bagasse. Comparing sugarcane bagasse and $B$. brizantha, it can be observed that sugarcane bagasse was the most susceptible to carbohydrate loss in the form of furfural and HMF. In the harshest condition, furfural release from sugarcane bagasse was 1.7 times higher than from $B$. brizantha. Similarly, HMF release was 9.4 times higher for bagasse. Considering HMF release, similar results were obtained when different pretreatment conditions were tested for sugarcane bagasse and other perennial grasses pretreated with sulfuric acid [13]. In this study, about $220 \mu \mathrm{g} / \mathrm{g}$ of HMF were detected in sugarcane bagasse hydrolysate after pretreatment at $180^{\circ} \mathrm{C}$, the highest concentration among the tested biomasses. However, different from the results in the present study, furfural production was higher for perennial grasses, especially for $B$. brizantha pretreated at $180^{\circ} \mathrm{C}$.

HMF concentrations in the range 1-5 g/L affect the yeast growth rate, fermentation rate and cell composition, but the main effect is related to an increase in the lag phase [50]. The ethanol yield in a study using a xylose-assimilating $S$. cerevisiae strain showed an increase after the addition of moderate concentrations of furfural to the culture medium [51]. In addition, model fermentation studies have shown that $S$. cerevisiae tolerates the addition of relatively high concentrations of furan aldehydes $[52,53]$. Therefore, the low concentrations of furfural and HMF generated by pretreatment of $B$. brizantha suggest that the growth rate and ethanol yields in fermentation by $S$. cerevisiae are not affected by these inhibitors.

The release of reducing sugars is also a drawback of pretreatment as it can decrease sugar concentrations in the pretreated biomass. In the tested conditions, reducing sugar concentrations resulting from the hemicellulosic fraction increased as the acid concentration increased from 0.5 to $1 \%$. Between 1 and $2 \%$ acid there were no differences except for Brachiaria brizantha treated for 30 minutes. Sugarcane bagasse was more susceptible to sugar loss than Brachiaria brizantha (Table 4).

Table 4. Reducing sugar concentrations resulting from the hydrolysates.

\begin{tabular}{|c|c|c|c|c|}
\hline \multirow{3}{*}{ Biomass } & \multirow{3}{*}{$\mathrm{H}_{2} \mathrm{SO}_{4}(\%)$} & \multicolumn{3}{|c|}{ Reducing sugars $(\mathrm{g} / \mathrm{g})$} \\
\hline & & \multicolumn{3}{|c|}{ Reaction time } \\
\hline & & $30 \mathrm{~min}$ & $60 \min$ & $90 \mathrm{~min}$ \\
\hline \multirow{3}{*}{ Brachiaria brizantha } & $0.5 \%$ & $0.187^{\mathrm{aA}}$ & $0.211^{\mathrm{bA}}$ & $0.225^{\mathrm{cA}}$ \\
\hline & $1.0 \%$ & $0.251^{\mathrm{aB}}$ & $0.360^{\mathrm{bB}}$ & $0.397^{\mathrm{cB}}$ \\
\hline & $2.0 \%$ & $0.308^{a C}$ & $0.360^{\mathrm{bB}}$ & $0.393^{\mathrm{cB}}$ \\
\hline \multirow{3}{*}{ Sugarcane bagasse } & $0.5 \%$ & $0.474^{\mathrm{aA}}$ & $0.477^{\mathrm{aA}}$ & $0.538^{\mathrm{bA}}$ \\
\hline & $1.0 \%$ & $0.501^{\mathrm{aB}}$ & $0.524^{\mathrm{aB}}$ & $0.537 b^{A}$ \\
\hline & $2.0 \%$ & $0.510^{\mathrm{aB}}$ & $0.518^{\mathrm{aB}}$ & $0.534 \mathrm{a}^{\mathrm{A}}$ \\
\hline
\end{tabular}

${ }^{*}$ Equal capital letters in the column and lower case letters in the row do not differ significantly $(P>0.05)$.

Considering the carbohydrate concentration, sugar losses and inhibitors production, the best pretreatment for sugarcane bagasse would be the use of $0.5 \%$ sulfuric acid with a retention time of 30 minutes. In this condition, it is possible to obtain a high glucan content and the production of inhibitors is the lowest. For $B$. brizantha, the best condition is $1 \%$ acid and 60 minutes or $2 \%$ and 60 minutes. In these conditions the carbohydrate content is optimized and inhibitor concentrations are not the highest.

\section{Simultaneous Saccharification and Fermentation (SSF)}

To verify the influence of different severity conditions of the dilute acid pretreatments on the $B$. brizantha grass and sugarcane bagasse structures, SSF was performed for both biomasses pretreated under diverse conditions. Figure 1 shows the results of SSF for $B$. brizantha grass and sugarcane bagasse submitted to the analyzed pretreatments: the mildest with $0.5 \%$ sulfuric acid for 30 minutes (Treatment 1 ), and the condition of $2 \%$ sulfuric acid for 60 minutes (Treatment 2).

Pre-hydrolysis was conducted in the SSF experiments since it improves the conditions for sugar fermentation by the yeast. Moreover, inoculating pre-cultivated yeast prevents sugar consumption for growth and not fermentation. Therefore, better ethanol yields from high initial glucose concentration are observed [54]. The release of glucose from pretreated biomasses was higher when the harsher condition was used (Figure 1). This result reflects the difference in glucan concentration obtained from the biomasses considering these two conditions (Table 2). Because the glucan concentration was higher when the pretreatment with 2 $\%$ acid for 60 minutes was applied to the biomasses, the glucose concentration in SSF was also higher than that obtained using $1 \%$ and 30 minutes. 
A

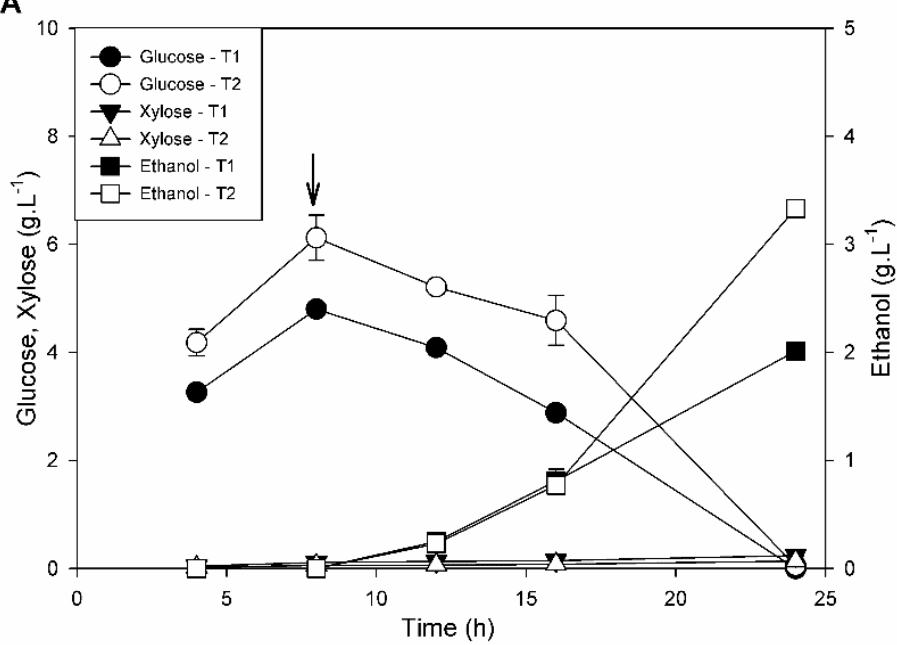

B

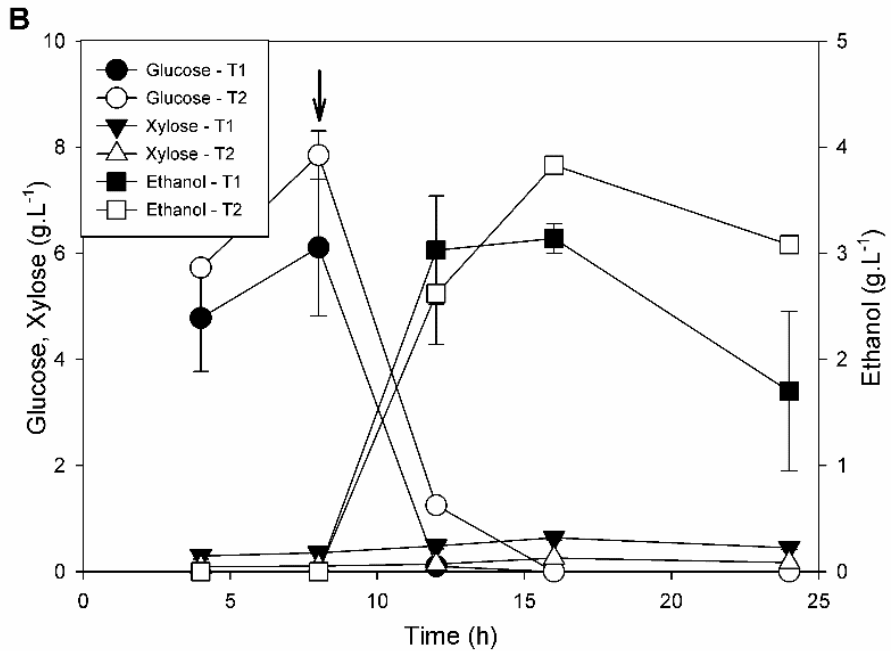

Figure 1. Concentrations of glucose, xylose and ethanol at different times during the fermentation process (SSF) using pretreated Brachiaria brizantha grass (A) and sugarcane bagasse (B) as substrates. T1 corresponds to the pretreatment with $0.5 \%$ sulfuric acid for $30 \mathrm{~min}$, and T2 to the pretreatment with $2 \%$ sulfuric acid for $60 \mathrm{~min}$. The arrows indicate the time when the yeast was inoculated in the fermentation medium.

Fermentation results for $B$. brizantha showed that increasing the acid pretreatment severity did not decrease glucose assimilation by the yeast. The concentrations of inhibitors produced in the tested conditions were not enough to inhibit fermentation, indicated by the great increase in ethanol production. In this case, it is suggested that the degradation of cellulose occurred even if there was a considerable formation of HMF (Table 3). During fermentation, glucose released by hydrolysis of the carbohydrates from the grass and sugarcane bagasse was totally consumed by the yeast after 24 and $16 \mathrm{~h}$, respectively, where the highest yields of ethanol were obtained for both treatments (Figure 1). The maximum saccharification efficiency (ethanol yield), approximately $46 \%$, was obtained after saccharification of $B$. brizantha pretreated with $2 \%$ sulfuric acid for 60 minutes. This ethanol yield was reached after $24 \mathrm{~h}$ of fermentation. The fermentation efficiency of sugarcane bagasse from the same pretreatment was $33 \%$, after $16 \mathrm{~h}$ of fermentation. On the other hand, the maximum efficiency obtained for both biomasses was very similar when submitted to pretreatment with $0.5 \%$ sulfuric acid for $30 \mathrm{~min}$, reaching approximately $30 \%$.

Similarly, Karimi and coauthors [55] obtained a maximum ethanol yield of $40.6 \%$ when using rice straw after pretreatment with $0.5 \%$ sulfuric acid for $20 \mathrm{~h}$ in SSF with $15 \mathrm{FPU}$ per gram of dry biomass and the yeast Saccharomyces cerevisiae [55]. An optimized enzymatic extract from Fusarium verticillioides was used for sugarcane bagasse hydrolysis and fermentation in a SSF process and the obtained yield was $52 \%$ [43]. Brachiaria brizantha pretreated with low moisture anhydrous ammonia was also submitted to SSF and resulted in an ethanol yield of $76.7 \%$ [56].

\section{Morphological analyzes}

Pretreatment of lignocellulosic biomass is performed to disorganize the cell wall structure and to favor enzymes accessibility. In order to better visualize this effect, scanning electron microscopy analyses (SEM) were carried out on raw materials and for the samples after the two different acid pretreatments: $0.5 \%$ acid for 30 minutes and $2 \%$ acid for 90 minutes, the milder and the more severe methods, respectively.

The untreated $B$. brizantha structure shows preserved carbohydrate fibers which can be seen as longitudinal bundles and also intact vessel elements (Figures 2A and B). After the mild pretreatment, some fiber bundles around the xylem were still preserved but some scratches were observed (Figure 2C). After the more severe pretreatment, fiber bundles were deconstructed and it is possible to visualize a lignin layer around the xylem (Figure 2E). Acid pretreatment, independent of its severity, caused damage to the vast majority of parenchyma cells (Figures 2D and F). 

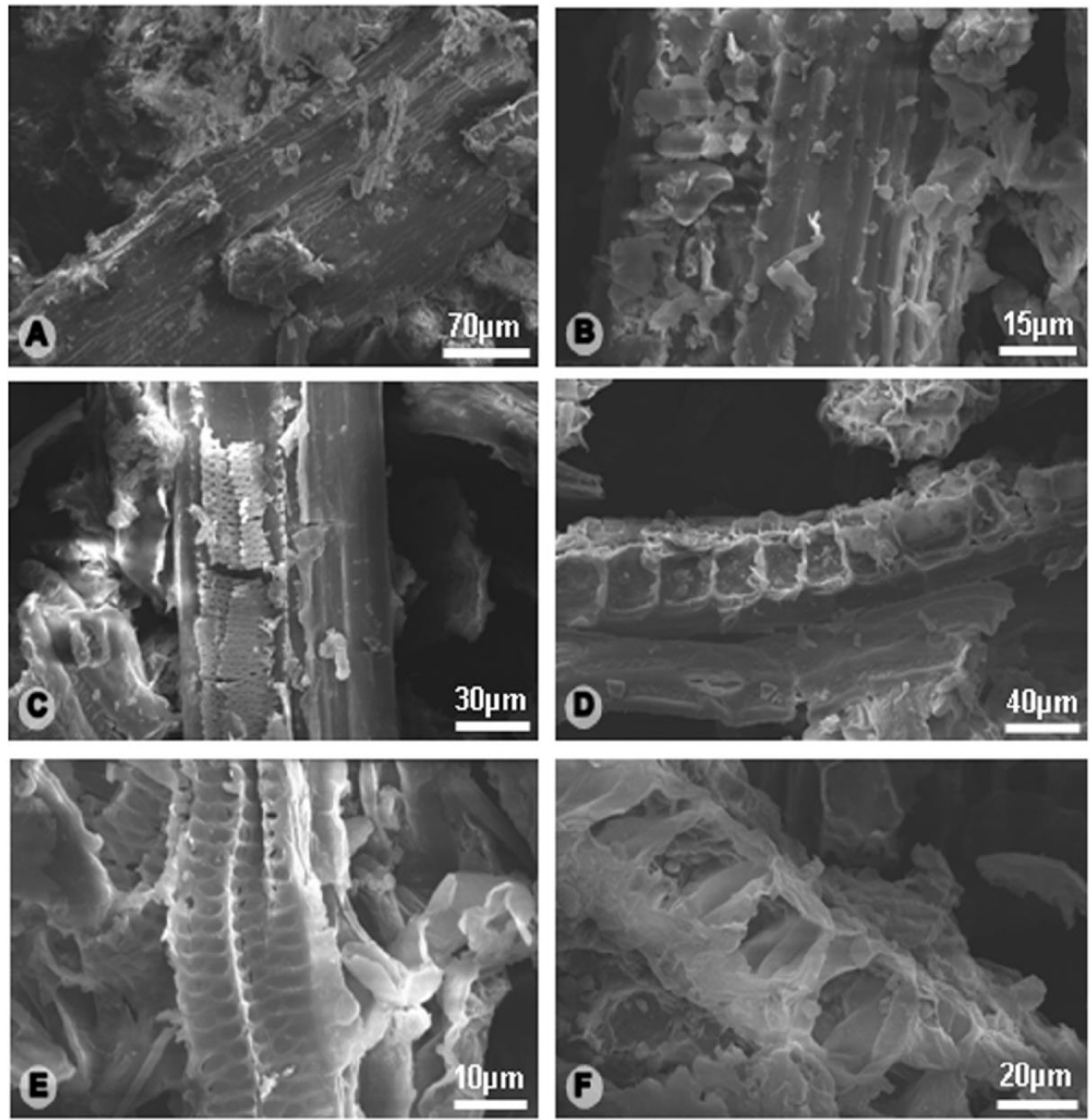

Figure 2. Scanning electron microscopy of Brachiaria brizantha grass samples: (A) and (B) xylem elements from untreated $B$. brizantha samples; (C) xylem elements and (D) parenchyma cells from B. brizantha treated with $0.5 \%$ sulfuric acid for 30 minutes; $(E)$ xylem elements and $(F)$ parenchyma cells from grass treated with $2 \%$ sulfuric acid for 90 minutes.

Raw sugarcane bagasse, bagasse submitted to 30 minutes with $0.5 \%$ acid pretreatment and after 90 minutes with $2 \%$ acid pretreatment were also analyzed (Figure 3 ). In raw sugarcane bagasse, intact xylem elements were observed in a fibrillary morphology presenting a highly ordered surface structure (Figures $3 \mathrm{~A}$ and B). Acid pretreatment caused different degrees of damage to these elements according to the tested conditions. Scratches can be observed on mildly pretreated samples (Figures $3 \mathrm{C}$ and $\mathrm{D}$ ), indicating that the structure was at least partially deconstructed. After a more severe pretreatment, the cell wall was opened and several disruption points were observed (Figures 3E and F). 

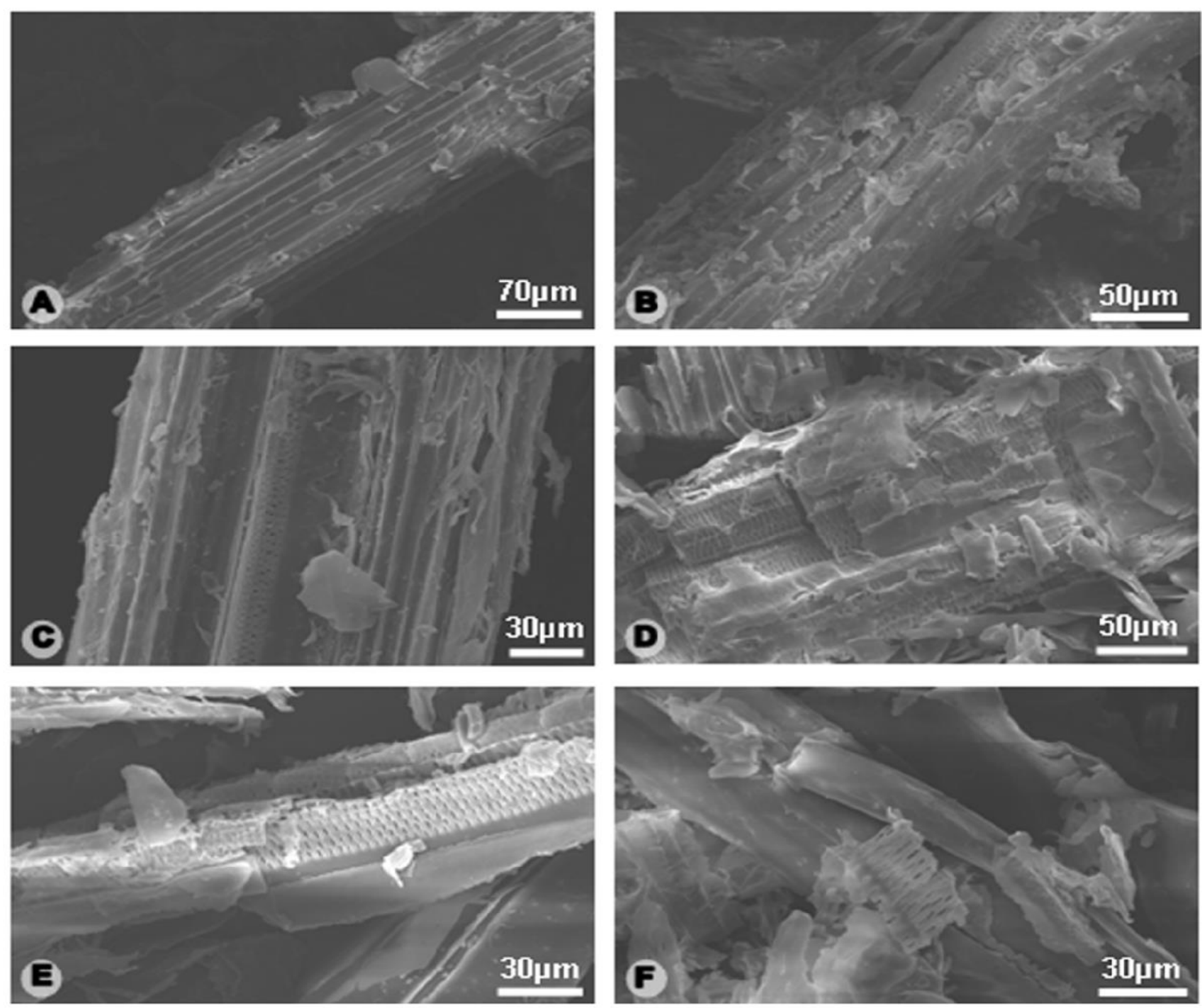

Figure 3. Scanning electron microscopy of sugarcane bagasse samples: $(A)$ and $(B)$ xylem elements from untreated sugarcane bagasse samples; (C) and (D) xylem elements treated with $0.5 \%$ sulfuric acid for 30 minutes; $(E)$ and $(F)$ xylem elements from sugarcane bagasse treated with $2 \%$ sulfuric acid for 90 minutes.

The effects of acid pretreatment on both biomasses morphology agree with the classical effects of fiber rupture and lignin concentration. This effect could also be observed for sugarcane bagasse treated with 0.1 $\mathrm{mol} / \mathrm{L}$ sulfuric acid at $130^{\circ} \mathrm{C}$. In this study, cellulose bundles from the pretreated biomass were more evident and showed fissures between them. This effect was associated with the high level of cellulose removal [13].

\section{CONCLUSION}

The grass Brachiaria brizantha and sugarcane bagasse were pretreated with $0.5,1$ or $2 \%$ acid for 30 , 60 or 90 minutes and the effects of these conditions on ethanol production were evaluated. Fibers of both biomasses were partially deconstructed by the tested conditions, indicating their effectiveness. The fermentation inhibitors furfural and hydroxymethylfurfural were produced in increasing concentrations, however fermentation was not critically affected by them. The grass $B$. brizantha showed a higher efficiency for conversion of the released glucose into ethanol than sugarcane bagasse. Because grass can be produced in many countries with high yields, it was concluded that this is a very interesting lignocellulosic biomass for 2G-ethanol production or for any other fermentation products.

Funding: This study was supported by grants of the Fundação de Amparo à Pesquisa do Estado de Minas Gerais FAPEMIG and Coordenacão de Aperfeiçoamento de Pessoal de Nível Superior - CAPES, Brazil.

Conflicts of Interest: The authors declare no conflict of interest. The organizations that financially supported this study had no role in the design of the study, in the collection, analyses, or interpretation of data, in the writing of the manuscript, or in the decision to publish the results. 


\section{REFERENCES}

1. Raud M, Kikas T, Sippula O, Shurpali NJ. Potentials and challenges in lignocellulosic biofuel production technology. Renew Sustain Energy Rev. 2019;111(2018 Jul):44-56.

2. Maitan-Alfenas GP, Visser EM, Guimarães V ria M. Enzymatic hydrolysis of lignocellulosic biomass: Converting food waste in valuable products. Curr Opin Food Sci. 2015;1(1):44-9.

3. Lin Y, Tanaka S. Ethanol fermentation from biomass resources: Current state and prospects. Appl Microbiol Biotechnol. 2006;69(6):627-42.

4. John MJ, Thomas S. Biofibres and biocomposites. 2008;71:343-64.

5. Ying Y, Teong K, Nadiah W, Abdullah W, Peng C. The world availability of non-wood lignocellulosic biomass for the production of cellulosic ethanol and potential pretreatments for the enhancement of enzymatic sacchari fi cation. Renew Sustain Energy Rev. 2016;60:155-72.

6. CONAB. Acompanhamento da sfra brasileira: Cana-de-açúcar. Bol CONAB - Cia Nac Abast. 2019;6(1):1-58.

7. ANP. Anuário estatístico brasileiro do petróleo, gás natural e biocombustíveis: 2019. Agência Nacional do Petróleo, Gás Natural e Biocombustíveis - ANP. 2019. Available in: <http://www.anp.gov.br>. Accessed in January, 2020.

8. Carpio LGT, de Souza FS. Competition between Second-Generation Ethanol and Bioelectricity using the Residual Biomass of Sugarcane : Effects of Uncertainty on the Production Mix. Molecules. 2019;24(369):1-15.

9. Karia CT, Duarte JB, de Araújo ACG. Desenvolvimento de cultivares do gênero Brachiaria (trin.) Griseb. no Brasil. Embrapa - Empres Bras Pesqui Agropecuária. 2006;163:1-58.

10. Alves E, Cristina F, Galvão A, Lúcia A. Plant Physiology and Biochemistry Influence of water limitation on the competitive interaction between two Cerrado species and the invasive grass Brachiaria brizantha cv . Piatã. Plant Physiol Biochem. 2019;135(2018 Aug):206-14 .

11. Jank L, Barrios SC, Do Valle CB, Simeão RM, Alves GF. The value of improved pastures to Brazilian beef production. Crop Pasture Sci. 2014;65(11):1132-7.

12. Umami N, Widodo S, Suhartanto B, Suwignyo B, Suseno N, Noviandi CT. The effect of planting material on nutrient quality and production of brachiaria spp. In Yogyakarta, Indonesia. Pakistan J Nutr. 2018;17(12):671-6.

13. Lima MA, Gomez LD, Steele-king CG, Simister R, Bernardinelli OD, Carvalho MA, et al. Evaluating the composition and processing potential of novel sources of Brazilian biomass for sustainable biorenewables production. Biotechnol Biofuels. 2014;7(10):1-19.

14. Speda J, Johansson MA, Odnell A, Karlsson M. Enhanced biomethane production rate and yield from lignocellulosic ensiled forage ley by in situ anaerobic digestion treatment with endogenous cellulolytic enzymes. Biotechnol Biofuels. 2017;10(129):1-13.

15. de Almeida MN, Falkoski DL, Guimarães VM, Rezende ST De. Study of gamba grass as carbon source for cellulase production by Fusarium verticillioides and its application on sugarcane bagasse saccharification. Ind Crop Prod. 2019;133(2018 Oct):33-43.

16. Reddy KO, Maheswari CU, Dhlamini MS, Mothudi BM, Kommula VP, Zhang J, et al. Extraction and characterization of cellulose single fibers from native african napier grass. Carbohydr Polym. 2018;188(Jan):85-91.

17. Hendriks ATWM, Zeeman G. Pretreatments to enhance the digestibility of lignocellulosic biomass. Bioresour Technol. 2009;100(1):10-8.

18. Guimar OC, Neto AC, Jos M, Guimarães MJOC, Freire E. Business models for commercial scale secondgeneration bioethanol production. J Clean Prod. 2018;184:168-78.

19. Furtado AT, Hekkert MP, Negro SO. Of actors, functions, and fuels: Exploring a second generation ethanol transition from a technological innovation systems perspective in Brazil. Energy Res Soc Sci [Internet]. 2020 Jul;70:101706. Available from: https://doi.org/10.1016/j.erss.2020.101706

20. Manmai N, Unpaprom Y, Ponnusamy VK, Ramaraj R. Bioethanol production from the comparison between optimization of sorghum stalk and sugarcane leaf for sugar production by chemical pretreatment and enzymatic degradation. Fuel [Internet]. 2020 May;278:118262. Available from: https://doi.org/10.1016/j.fuel.2020.118262

21. Falkoski DL, Guimarães VM, De Almeida MN, Alfenas AC, Colodette JL, De Rezende ST. Characterization of cellulolytic extract from Pycnoporus sanguineus PF-2 and its application in biomass saccharification. Appl Biochem Biotechnol. 2012;166(6):1586-603.

22. Chen X, Zhai R, Shi K, Yuan Y, Dale BE, Gao Z, et al. Mixing alkali pretreated and acid pretreated biomass for cellulosic ethanol production featuring reduced chemical use and decreased inhibitory effect. Ind Crops Prod [Internet]. 2018 Jun;124:719-25. Available from: https://doi.org/10.1016/j.indcrop.2018.08.056

23. Santosh I, Ashtavinayak P, Amol D, Sanjay P. Enhanced bioethanol production from different sugarcane bagasse cultivars using co-culture of Saccharomyces cerevisiae and Scheffersomyces (Pichia) stipitis. J Environ Chem Eng [Internet]. 2017;5(3):2861-8. Available from: http://dx.doi.org/10.1016/j.jece.2017.05.045

24. Yu H, Xiao W, Han L, Huang G. Characterization of mechanical pulverization / phosphoric acid pretreatment of 
corn stover for enzymatic hydrolysis. Bioresour Technol. 2019 Jan;282:69-74.

25. Robak K, Balcerek M. Current state-of-the-art in ethanol production from lignocellulosic feedstocks. Microbiol Res [Internet]. 2020 Jun;240:126534. Available from: https://doi.org/10.1016/j.micres.2020.126534

26. Maitan-alfenas GP, Michael E, Ferreira R, Ris B, Nogueira G, Galvão G, et al. The influence of pretreatment methods on saccharification of sugarcane bagasse by an enzyme extract from Chrysoporthe cubensis and commercial cocktails : A comparative study. Bioresour Technol. 2015;192:670-6.

27. Davaritouchaee M, Hiscox WC, Martinez-fernandez J, Fu X, Mancini RJ, Chen S. Effect of reactive oxygen species on biomass structure in di ff erent oxidative processes. Ind Crop Prod. 2019 May;137:484-94.

28. Iram A, Cekmecelioglu D, Demirci A. Optimization of dilute sulfuric acid, aqueous ammonia , and steam explosion as the pretreatments steps for distillers ' dried grains with solubles as a potential fermentation feedstock. Bioresour Technol. 2019 Mar;282:475-81.

29. Yuan Z, Wen Y, Sella N. Ethanol production from bamboo using mild alkaline pre-extraction followed by alkaline hydrogen peroxide pretreatment. Bioresour Technol. 2018;247(2017 Sep):242-9.

30. Wallis, A.F.A., Wearne, R.H., Wright PJ. Chemical analysis of polysaccharides in plantation eucalypt woods and pulps. Appita J. 1996;49(4):258-62.

31. Gomide, J.L. e Demuner BJ. Determinação do teor de lignina em material lenhoso: método Klason modificado. 0 Pap. 1986;47(8):36-8.

32. Nascimento RF, Cerroni JL, Cardoso DR, Lima Neto BS, Franco DW. Comparação Dos Métodos Oficiais De Análise E Cromatográficos Para a Determinação Dos Teores De Aldeídos E Ácidos Em Bebidas Alcoólicas. Ciência e Tecnol Aliment. 1998;18(3):350-6.

33. Zappala M, Fallico B, Arena E, Verzera A. Methods for the determination of HMF in honey: a comparison. Food Control. 2005;16:273-7.

34. Vassilev S V, Baxter D, Andersen LK, Vassileva CG. An overview of the chemical composition of biomass. Fuel. 2010;89(5):913-33.

35. Monti A, Di N, Venturi G. Mineral composition and ash content of six major energy crops. 2008;32:216-23.

36. Obernberger I, Brunner T, Ba G. Chemical properties of solid biofuels - significance and impact. 2006;30:97382.

37. Park BB, Yanai RD, Sahm JM, Lee DK, Abrahamson LP. Wood ash effects on plant and soil in a willow bioenergy plantation. 2005;28:355-65.

38. Schäfer J, Bunzel M. Characterization of Miscanthus cell wall polymers. 2019;(April 2018):191-205.

39. Yang H, Chen J, Chen Q, Wang K, Sun R. The Synergic Relationship Between Xylan Removal and Enhanced Cellulose Digestibility for Bioethanol Production: Reactive Area, Crystallinity, and Inhibitation. Bioenergy Res. 2015;8:1847-55.

40. Wongwatanapaiboon J, Kangvansaichol K, Burapatana V, Inochanon R, Winayanuwattikun P, Yongvanich T, et al. The Potential of Cellulosic Ethanol Production from Grasses in Thailand. 2012;2012.

41. Helena L, Cândida S, Carvalho A. Effects of the pretreatment method on high solids enzymatic hydrolysis and ethanol fermentation of the cellulosic fraction of sugarcane bagasse. Bioresour Technol. 2015;191:312-21.

42. Rezende CA, Lima MA De, Maziero P, Ribeiro E. Chemical and morphological characterization of sugarcane bagasse submitted to a delignification process for enhanced enzymatic digestibility Chemical and morphological characterization of sugarcane bagasse submitted to a delignification process for enhanc. Biotechnol Biofuels. 2011;4(1):54.

43. De Almeida MNMN, Guimarães VMVM, Falkoski DLDL, Paes GBTBTTGBT, Ribeiro Jl, Visser EMEM, et al. Optimization of endoglucanase and xylanase activities from Fusarium verticillioides for simultaneous saccharification and fermentation of sugarcane bagasse. Appl Biochem Biotechnol [Internet]. 2014 Feb [cited 2016 Sep 15];172(3):1332-46. Available from: http://link.springer.com/10.1007/s12010-013-0572-9

44. Visser EMEMEMEMEM, Leal TFTF, de Almeida MNMN, Guimarães VMVM. Increased enzymatic hydrolysis of sugarcane bagasse from enzyme recycling. Biotechnol Biofuels [Internet]. 2015 [cited 2016 Sep 15];8(1):5. Available from: http://biotechnologyforbiofuels.biomedcentral.com/articles/10.1186/s13068-014-0185-8

45. Akanksha K, Prasad A, Sukumaran RK, K MN, Pandey A. Dilute acid pretreatment and enzymatic hydrolysis of sorghum biomass for sugar recovery - A statistical approach. 2014 Nov;52:1082-9.

46. Kucharska K, Rybarczyk P, Hołowacz I, Łukajtis R. Pretreatment of Lignocellulosic Materials as Substrates for Fermentation Processes.1-32.

47. Sun Y, Cheng JJ. Dilute acid pretreatment of rye straw and bermudagrass for ethanol production. 2005;96:1599606.

48. Redding AP, Wang Z, Keshwani DR, Cheng JJ. High temperature dilute acid pretreatment of coastal Bermuda grass for enzymatic hydrolysis. Bioresour Technol. 2011;102(2):1415-24. 
49. Sun C, Xia A, Liao Q, Guo X, Fu Q, Huang Y, et al. Inhibitory effects of furfural and vanillin on two-stage gaseous biofuel fermentation. Fuel. 2019 Mar;252:350-9.

50. Taherzadeh MJ, Gustafsson L, Niklasson C, Lidén G. Physiological effects of 5-hydroxymethylfurfural on Saccharomyces cerevisiae. Appl Microbiol Biotechnol. 2000;53(6):701-8.

51. Wahlbom CF, Hahn-Hägerdal B. Furfural, 5-hydroxymethyl furfural, and acetoin act as external electron acceptors during anaerobic fermentation of xylose in recombinant Saccharomyces cerevisiae. Biotechnol Bioeng. 2002;78(2):172-8.

52. Cavka A, Alriksson B, Ahnlund M, Jönsson LJ. Effect of sulfur oxyanions on lignocellulose-derived fermentation inhibitors. Biotechnol Bioeng. 2011;108(11):2592-9.

53. Larsson S, Palmqvist E, Hahn-Hägerdal B, Tengborg C, Stenberg K, Zacchi G, et al. The generation of fermentation inhibitors during dilute acid hydrolysis of softwood. Enzyme Microb Technol. 1999;24(3-4):151-9.

54. Li X, Lu J, Zhao J, Qu Y. Characteristics of Corn Stover Pretreated with Liquid Hot Water and Fed- Characteristics of Corn Stover Pretreated with Liquid Hot Water and Fed-Batch Semi-Simultaneous Saccharification and Fermentation for Bioethanol Production. 2014 Jul.

55. Karimi K, Kheradmandinia S, Taherzadeh MJ. Conversion of rice straw to sugars by dilute-acid hydrolysis. Biomass and Bioenergy. 2006;30(3):247-53.

56. Yasuda M, Takenouchi Y, Nitta Y. Italian ryegrass ( Lolium multiflorum Lam ) as a High-Potential Bio-Ethanol Resource. Bioenergy Res. 2015;8:1303-9.

cC (7) ( ${ }^{\odot} 2021$ by the authors. Submitted for possible open access publication under the terms and cc) (1) (5) conditions of the Creative Commons Attribution (CC BY NC) license EY NC (https://creativecommons.org/licenses/by-nc/4.0/). 